\title{
PENANAMAN NILAI PENDIDIKAN AGAMA HINDU MELALUI PENGABDIAN KEPADA MASYARAKAT DI PASRAMAN AMERTHA SANJIWANI RINCUNG
}

\author{
I Wayan Rudiarta1) \\ 1)Program Studi Pendidikan Agama Hindu, Fakultas Dharma Acarya, IAHN Gde Pudja Mataram, Mataram, Indonesia \\ Corresponding author : I Wayan Rudiarta \\ E-mail : iwayanrudiarta@iahn-gdepudja.ac.id
}

Diterima 22 Agustus 2021, Direvisi 04 Agustus 2021, Disetujui 04 Agustus 2021

\begin{abstract}
ABSTRAK
Tulisan ini bertujuan untuk mempublikasikan hasil kegiatan pengabdian kepada Masyarakat yang dilaksanakan di Pasraman Amertha Sanjiwani, Dusun Rincung, Desa Banyu Urip, Kecamatan Gerung, Kabupaten Lombok Barat. Kegiatan yang ditekankan pada tulisan ini adalah mengenai penanaman nilai-nilai Pendidikan Agama Hindu atau nilai karakter mulia kepada para siswa pasraman. Kegiatan pengabdian dilakukan dalam enam rangkaian kegiatan, yang mencakup Perencanaan Kegiatan Pengabdian, Survei Lokasi, Analisis Kebutuhan Pengabdian, Perencanaan Pembelajaran Pendidikan Agama Hindu, Penanaman Nilai Pendidikan Agama Hindu dan Evaluasi Kegiatan. Melalui kegiatan pembelajaran Pendidikan Agama Hindu, penanaman nilai karakter dapat dilakukan melalui pendekatan holistic dan mempertimbangkan faktor kultur yang berlaku di masyarakat. Dengan memperhatikan protokol kesehatan Covid-19, pembelajaran dilaksanakan dengan menerapkan metode Dharma Wacana dikolaborasikan dengan metode Dharma Tula dan Demonstrasi. Kombinasi tiga metode belajar tersebut mampu membuat siswa antusias belajar. Sebagai hasil kegiatan, terlihat mulai tertanam benihbenih nilai religius, ramah tamah dan sopan santun, disiplin dan sikap peduli pada diri siswa. Hal ini tentunya menjadi tanggung jawab bersama untuk mampu menjaga berkembangnya nilai positif pada siswa yang akan berimplikasi pada kemajuan masyarakat ke depannya.
\end{abstract}

Kata Kunci: penanaman nilai; pendidikan; agama hindu; pasraman.

\begin{abstract}
This paper aims to publish the results of community service activities carried out at the Amertha Sanjiwani Pasraman, Rincung Hamlet, Banyu Urip Village, Gerung District, West Lombok Regency. The activities emphasized in this paper are about internalisation Hindu religious education values or noble character values to pasraman students. Service activities are carried out in six series of activities, which include Service Activity Planning, Location Surveis, Needs Analysis, Hindu Religious Education Learning Planning, Hindu Religious Education Values and Evaluation. Through Hindu Religious Education learning activities, the internalisation of character values can be done through a holistic approach and considers cultural factors that apply in society. By paying attention to the Covid-19 health protokol, learning is carried out by applying the Dharma Wacana method in collaboration with the Dharma Tula and Demonstration methods. The combination of the three learning methods is able to make students enthusiastic about learning. As a result of the activity, it seems that the seeds of religious values, hospitality and courtesy, discipline and caring attitudes are starting to be planted in students. This is of course a shared responsibility to be able to maintain the development of positive values in students which will have implications for the progress of society in the future.
\end{abstract}

Keywords: value internalisation; education; hinduism; pasraman.

\section{PENDAHULUAN}

Pengabdian kepada Masyarakat merupakan salah satu Tri Dharma Perguruan Tinggi yang harus dilaksanakan oleh seorang dosen. Melalui Pengabdian kepada Masyarakat, dosen mendapat kesempatan untuk mengaplikasikan konsep-konsep teori yang telah dikaji untuk diterapkan dalam kehidupan bermasyarakat. Berinteraksi secara langsung dengan masyarakat juga memberikan peluang bagi dosen untuk menemukan berbagai permasalahan yang terjadi di masyarakat untuk kemudian dijadikan sebuah permasalahan yang bisa menjadi objek penelitian.

Sekolah Tinggi Agama Hindu Negeri Gde Pudja Mataram sebagai salah satu perguruan tinggi keagamaan Hindu yang terletak di Provinsi Nusa Tenggara Barat juga ambil bagian dalam pengembangan Tri Dharma Perguruan Tinggi. Kampus Keagamaan Hindu yang memiliki visi menjadi pusat kajian Hindu 
yang unggul dan berdaya saing ini secara rutin membiayai Pengabdian kepada Masyarakat untuk para dosen. Pengabdian kepada Masyarakat mengambil lokasi di daerah-daerah yang terdapat masyarakat Hindu, sehingga selain mengaplikasikan konsep teori yang ada, melalui pengabdian ini juga memberikan pembinaan kepada umat Hindu berkaitan dengan pemahaman ajaran Agama.

Sekolah Tinggi Agama Hindu Negeri Gde Pudja Mataram, melalui Program Studi Pendidikan Agama Hindu melakukan pengabdian kepada Masyarakat di Pasraman Amertha Sanjiwani Dusun Rincung, Desa Banyu Urip, Kecamatan Gerung, Kabupaten Lombok Barat. Program Studi Pendidikan Agama Hindu, sebagai salah satu program studi ilmu keguruan menyasar pasraman. Pasraman merupakan lembaga tempat berlangsungnya pembelajaran agama Hindu (Subagia, 2016). Pasraman ada yang formal dan non formal, sementara Pasraman Amertha Sanjiwani merupakan pasraman Non formal, yang secara system pembelajaran berbeda dengan sekolah formal pada umumnya.

Pendidikan Agama Hindu menjadi salah satu muatan yang diberikan kepada para siswa pasraman Amertha Sanjiwani dalam pengabdian masyarakat yang dilakukan. Pendidikan Agama Hindu menjadi salah satu muatan yang dianggap penting karena melalui pendidikan agama Hindu para siswa dapat diberikan penanaman nilai-nilai keagamaan Hindu sehingga tidak kaya secara konsep tetapi miskin secara aplikasi. Ajaran agama adalah ajaran nilai, yang mana nilai akan banyak dirasakan melalui sebuah pola tingkah laku.

Penanaman nilai-nilai ajaran agama akan berkorelasi dengan penanaman karakter atau akhlak mulia pada siswa. Pendidikan agama Hindu mendukung terbentuknya akhlak mulia dan sikap budhi pekerti yang luhur. Selain itu, dengan pendidikan agama Hindu juga disebutkan dapat menunjang terwujudnya perilaku kedewataan (Daiwi Sampad) bagi para generasi muda Hindu. Ajaran agama Hindu yang bersumber dari kitab suci Veda selalu memberikan tuntunan agar umat senantiasa berprilaku berdasarkan dharma guna menuju kedamaian (Santih) (Santika, 2018).

Di era disrupsi ini, generasi muda lebih menyukai sebuah konsep ajaran yang lebih menonjolkan Teknologi Informasi. Ajaran yang sifatnya orthodox seperti ajaran agama kadang dipandang sebelah mata, sehingga banyak kasus yang terjadi menunjukkan kemerosotan moral generasi muda. Salah satu contoh kasusnya sebagaimana yang dapat ditonton melalui chanel youtube https://www.youtube.com/watch?v=IAPUvYh0o
Q4, yang mana seorang anak tega menganiaya ibu kandungnya hanya karena tidak diberikan uang. Sungguh ironi, bagaimana seorang lbu yang membesarkan anaknya, kini menjadi sasaran amukan anaknya hanya karena masalah kecil.

Melalui pengabdian kepada Masyarakat di Pasraman Amertha Sanjiwani, dengan rata-rata siswa berusia antara 8-12 tahun, Tim Pengabdian Prodi Pendidikan Agaam Hindu akan berupaya untuk memberikan bekal-bekal berupa penanaman konsep dan konsteks dengan mengacu pada local wisdom atau local genius yang berlaku di lingkungan masyarakat setempat.

Menurut Gunada dkk (2021), sebagian besar warga Dusun Rincung merupakan warga asli Bali yang telah lama tinggal di Lombok, sehingga secara adat dan budaya tidak jauh berbeda dari budaya leluhurnya di Bali. Hal ini tentunya memudahkan tim pengabdian kepada Masyarakat yang juga merupakan Hindu holistik Bali. Penekanan ajaran agama Hindu yang dibaluti kearifan lokal setempat diharapkan mampu menjadi strategi yang baik guna menanaman nilai-nilai karakter.

Kegiatan Pengabdian kepada

Masyarakat Program Studi Pendidikan Agama Hindu bertujuan untuk memberikan penanaman nilai karakter kepada siswa Pasraman Amertha Sanjiwani sejak usia dini. Dengan penanaman nilai-nilai karakter sejak dini, siswa akan mendapatkan bekal untuk tumbuh dan mendewasa. Penanaman nilai-nilai karakter dilakukan dengan memadukan ajaran agama Hindu dan kearifian lokal masyarakat setempat. Generasi muda kerapkali disebut sebagai agen perubahan (agent of change), sehingga dengan melahirkan para generasi muda yang berkarakter tentunya kita telah berupaya untuk menciptakan masa depan bangsa yang indah dan penuh keharmonisan.

\section{METODE}

Kegiatan Pengabdian kepada Masyarakat Program Studi Pendidikan Agama Hindu bertempat di Pasraman Amertha Sanjiwani dengan prioritas utama menyasar Siswa Pasraman Amertha Sanjiwani yang berjumlah 24 orang. Kegiatan ini terlaksana dengan mendapatkan dukungan dari Kampus STAHN Gde Pudja Mataram (yang saat ini sudah beralih status menjadi IAHN Gde Pudja Mataram) dan seluruh pemuka masyarakat di Dusun Rincung, Desa Banyu Urip, Kecamatan Gerung Lombok Barat.

Kegiatan Pengabdian kepada Masyarakat ini dilakukan dengan metode pelaksanaan Kegiatan yang secara umum 
dibagi menjadi enam kegiatan, yaitu tersaji dalam bagan berikut.

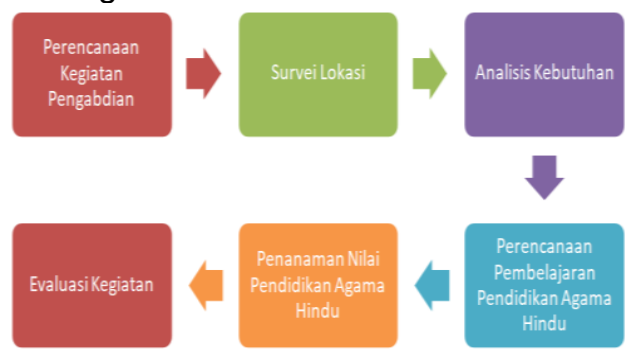

Gambar 1. Alur Kegiatan Penanaman NilaiNilai Karakter

Secara rinci alur kegiatan sebagaimana pada Gambar 1 dapat dijelaskan bahwa kegiatan pengabdian dilakukan melalui enam tahapan yang menjadi satu kesatuan yang utuh dan saling berkorelasi satu sama lain. Melalui kegiatan perencanaan kegiatan PKM, petunjuk pelaksanaan yang diberikan oleh Pusat Penelitian dan Pengabdian kepada Masyarakat (P3M) STAHN Gde Pudja Mataram diterjemahkan oleh panitia, sehingga berupaya mendata beberapa lokasi yang memungkinkan untuk melaksanakan kegiatan. Pada tahap perencanaan ini juga dibahas bentuk Pengabdian kepada Masyarakat yang akan dilakukan. Tahap perencanaan ini menjadi suatu tahapan yang sangat penting, karena perencanaan akan menjadi acuan dalam realisasi kegiatan.

Setelah tahap perencanaan selesai, dilakukan proses survei lokasi (telah ditentukan pada perencanaan) untuk kemudian disesuaikan dengan indikator yang telah disepakati. Pada saat melakukan survei lokasi, juga digali informasi mengenai keadaan demografis di lokasi, sehingga memudahkan dalam tahap berikutnya, yaitu analisis kebutuhan. Pada saat analisis kebutuhan ini, disamping menyepakati materi yang akan diberikan pada saat pelaksanaan Pengabdian kepada Masyarakat juga mendata bantuan apa saja yang akan diberikan kepada masyarakat, dalam hal ini adalah Pasraman Amertha Sanjiwani.

Sebagai salah satu materi yang akan diberikan dalam pengabdian kepada masyarakat, materi pendidikan agama Hindu juga perlu direncanakan. Dalam perencanaan ini, hampir sama dengan pembelajaran di kelas, yang harus membuat RPP (Rencana Pelaksanaan Pembelajaran) dan Silabus. Bedanya, dalam kegiatan Pengabdian kepada Masyarakat, yang lebih ditonjolkan adalah pemilihan strategi pembelajaran, yang meliputi metode dan tekhnik pembelajaran. Disamping itu, materi yang disusun juga tidak mengacu pada kurikulum, melainkan merujuk pada materi yang berkorelasi dengan tingkah laku sehari-hari.

Selanjutnya, pada tahap penanaman nilai Pendidikan Agama Hindu, materi dan strategi yang telah disiapkan digunakan dalam pembelajaran. Pada tahapan ini berlangsung proses korelasi konsep ajaran Hindu dengan perilaku sehari-hari siswa. Pemberian materi Pendidikan Agama Hindu, dilakukan pada hari pertama Pengabdian kepada Masyarakat yang diselenggarakan dalam waktu tujuh hari. Dan dalam waktu tujuh hari itu pula tim pengabdian melakukan evaluasi kepada para siswa, yang dilihat dari perubahan prilaku.

Kegiatan pengabdian kepada Masyarakat dilaksanakan pada tanggal 18-24 September 2020 dalam suasana pandemi Covid-19. Oleh karena itu dalam pelaksanan Pengabdian kepada Masyarakat ini, seluruh tim dan peserta selalu memperhatikan protokol kesehatan, yaitu menggunakan masker, dan selalu mencuci tangan atau paling tidak menggunakan hand sanitizer. Jumlah peserta juga dibatasi, sehingga terselenggaranya kegiatan tetap diharapkan tidak menjadi pemicu penyebaran Covid-19. Pengabdian kepada Masyarakat didesain dalam konsep yang lebih sederhana tanpa mengurangi makna. Hal ini dilakukan untuk tetap menyukseskan kewajiban dalam Tri Dharma Perguruan Tinggi tanpa mengesampingkan himbauan Pemerintah.

\section{HASIL DAN PEMBAHASAN}

Pendidikan karakter memang menjadi perbincangan yang seakan tiada hentinya. Hal ini dikarenakan karakter menjadi aspek yang begitu penting dalam perwujudan manusia sebagai makhluk sosial. Manusia tidak bisa hidup tanpa keberadaan orang lain di sekitarnya. Bersosialisasi menjadi ciri khas yang menggambarkan interaksi antara orang satu dengan orang lainnya. ketika berinteraksi inilah peran karakter akan terlihat. orang dengan karakter yang baik, akan selalu mampu berinteraksi dengan baik. Dalam jangka waktu yang panjang hal tersebut akan mempengaruhi cara seseorang berperilaku dalam kehidupannya di masyarakat.

Menanamkan karakter pada seseorang memang tidaklah mudah. Kalau mengajar bisa kita sebut menulis di atas batu, kendati sulit tetapi masih ada bekasnya, evaluasinya nyata. Sementara kalau menanamkan nilai karakter bisa disebut seperti menulis di atas air, terus dilakukan tetapi hasilnya tidak terlihat, sehingga evaluasinya menjadi sulit. Karakter sangat berkaitan dengan kepribadian seseorang, dan menjadi tugas berat ketika harus mengubah hal tersebut. Melihat hal tersebut, pengabdian kepada masyarakat yang dilakukan oleh prodi 
Pendidikan Agama Hindu STAHN Gde Pudja Mataram berupaya memberikan penanaman karakter untuk mewujudkan generasi muda Hindu yang beradab.

\section{Perencanaan Kegiatan melalui Rapat Tim Pengabdian kepada Masyarakat \\ Sebagaimana dalam sebuah}

manajemen, perencanaan menjadi komponen penting untuk dilakukan. Demikian halnya dengan kegiatan Pengabdian kepada Masyarakat oleh Prodi Pendidikan Agama Hindu, dilakukan kegiatan rapat Tim untuk membuat perencanaan pada tanggal 12 Agustus 2020. Dalam rapat yang dilakukan, dibahas beberapa hal yang mencakup tempat pelaksanaan, waktu pelaksanaan, tema pengabdian, dan desain kegiatan yang akan dilaksanakan.

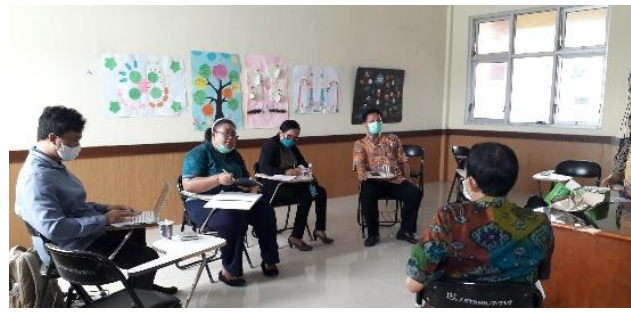

Gambar 2. Rapat Tim Pengabdian

(Sumber: I Wayan Rudiarta, 2020)

Setelah melakukan rapat tim sebagaimana yang terlihat pada Gambar 2, akhirnya diperoleh kesepakatan bahwa kegiatan akan dilaksanakan di Pasraman, sebagai lembaga pendidikan keagamaan Hindu yang merujuk pada Pasraman Amertha Sanjiwani Rincung. Waktu pelaksanaan direncanakan akan diselenggarakan pada pertengahan bulan September, yaitu antara hari raya Galungan dan Kuningan. Tema yang diusung dalam kegiatan pengabdian masyarakat prodi pendidikan Agama Hindu adalah "Implementasi Nilai-Nilai Pendidikan Agama Hindu di Era New Normal". Sementara untuk desain kegiatan, didesain secara sederhana dan dengan menghadirkan sedikit masyarakat, termasuk dalam kegiatan pembukaan dan penutupan kegiatan.

\section{Survei Lokasi Pengabdian kepada Masyarakat}

Sebagai bentuk tindak lanjut perencanaan yang telah dilakukan, pada tanggal 08 September 2020, beberapa anggota tim pengabdian kepada masyarakat melakukan Survei lokasi menuju pasraman Amertha Sanjiwani yang berlokasi di Dusun Rincung, Desa Banyu Urip Kecamatan Gerung. Sebelum melakukan survei, tim meminta bantuan salah satu mahasiswa yang berasal dari sana sebagai penyambung informasi kepada Ketua
Pasraman sehingga tim bisa diterima. Pada saat melakukan Survei, tim diterima secara langsung oleh Ketua Pasraman yang didampingi oleh kepala Dusun. I

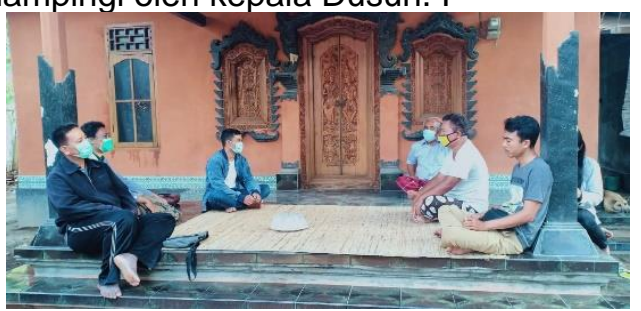

Gambar 3. Survei Lokasi Pengabdian

(Sumber: I Wayan Rudiarta, 2020)

Ketua Pasraman dan kepala Dusun menyambut baik kehadiran perwakilan tim pengabdian sebagaimana yang terlihat pada Gambar 3. Pada kesempatan itu pula terjadi diskusi antara tim dengan pihak pengelola pasraman yang diantaranya membahas keberadaan Pasraman Amertha Sanjiwani, kehidupan sosial masyarakat, serta membahas kiranya apa yang dibutuhkan dalam pengembangan pasraman ke depannya. Pasraman merupakan lembaga pendidikan Hindu yang berbasiss kearifan lokal, melalui Survei lokasi yang dilaksanakan nantinya diharapkan tim bisa memberikan materi sesuai kebutuhan dan mengena bagi kehidupan bermasyarakat disana. Kegiatan ini juga menjadi tahap pra kegiatan untuk melakukan diskusi, sharing dan menggali informasi (Yasa, 2021).

Pada saat Survei, tim juga berjumpa dengan anak-anak disana, yang kiranya secara sopan santun bisa dikatakan masih kurang. Hal ini terbukti ketika tim datang, melihat orang asing anak-anak disana datang berkerumun, kemudian melakukan "say hello" dengan cara yang kurang etis. Ketika tim melintas dengan kendaraan anak-anak dari kejauhan berteriak "Woy", sambil tertawa tidak karuan. Hal ini tentunya menjadi salah satu fenomena yang tim temukan dalam melakukan Survei lokasi yang akan menjadi salah satu pertimbangan dalam analisis kebutuhan.

\section{Analisis Kebutuhan Kegiatan Pasraman}

Analisis kebutuhan ini dilakukan oleh tim setelah melakukan kegiatan Survei lokasi. Melalui analisis kebutuhan diharapkan dapat memberikan gambaran terkait hal-hal yang memang harus dilakukan ketika melaksanakan kegiatan Pengabdian kepada Masyarakat. Adapun aspek yang dianalisis berkaitan dengan materi yang akan diberikan, bantuan yang akan diserahkan kepada pasraman, dan penyusunan jadwal kegiatan di tengah pandemic Covid-19. 
Setelah dilakukan analisis dengan pola yang sederhana, yaitu memperhatikan tempat pelaksanaan kegiatan, jumlah siswa pasraman, keadaan sosial masyarakat serta situasi pandemic Covid-19, disepakati:

a. Kegiatan akan dilaksanakan dalam waktu yang terbatas, yaitu maksimal 4 jam dalam sehari;

b. Melibatkan sedikit masyarakat, sehingga tidak menimbulkan kerumunan;

c. Materi yang akan diberikan pada saat Pengabdian kepada Masyarakat meliputi Materi Pendidikan Agama Hindu, Seni Lukis, Aksara Bali, Tari Bali, Yoga, dan Dharma Gita; dan

d. Jenis bantuan yang akan diserahkan kepada pihak pasraman berupa Papan Tulis, Sound System, dan Alas Praktek Yoga.

Hasil analisis kebutuhan yang telah ditelurkan oleh tim kemudian menjadi acuan dalam pelaksanaan kegiatan pengabdian yang disepakati berlangsung dari tanggal 18-24 September 2020. Hal ini mengingat pada tanggal 16 September 2020 adalah hari raya Galungan, sebagai perayaan kemenangan Dharma melawan Adharma, dan pada tanggal 26 September adalah hari raya kuningan, sebagai rangkaian hari raya Galungan. Disamping itu, hasil analisis kebutuhan ini juga menjadi acuan tim dalam pembuatan Term of Reference (TOR) dan Proposal Bantuan untuk diajukan ke lembaga.

\section{Perencanaan Pembelajaran Pendidikan Agama Hindu}

Mengacu pada analisis kebutuhan yang telah dilaksanakan, materi Pendidikan Agama Hindu menjadi salah satu muatan yang akan diajarkan dalam kegiatan pengabdian kepada masyarakat oleh Prodi Pendidikan Agama Hindu STAHN Gde Pudja Mataram. Dan pemberian materi inilah yang menjadi substansi yang akan penulis tekankan. Sehingga selanjutnya bentuk kegiatan pengabdian yang diungkap hanya berkaitan dengan pemberian materi Pendidikan Agama Hindu.

Sebagai mana kegiatan belajar mengajar di sekolah, sebelum memberikan materi di Pasraman, juga harus dibuat perencanaan pembelajaran. Perencanaan pembelajaran ini didefinisikan sebagai gambaran segala sesuatu yang akan dilakukan oleh guru dalam melangsungkan kegiatan pembelajaran (Nadlir, 2013). Melalui perencanaan pembelajaran yang matang, maka aktivitas (proses) pembelajaran juga akan mampu berjalan dengan baik menuju goal (tujuan) yang hendak dicapai. Tujuan dari pembelajaran bukan semata-mata hanya perkara nilai (peringkat), karena pembelajaran apapun yang dilakukan oleh seseorang akhirnya adalah tentang aktualisasi diri atau kemampuan menggali potensi yang ada pada diri (Rudiarta, 2020).

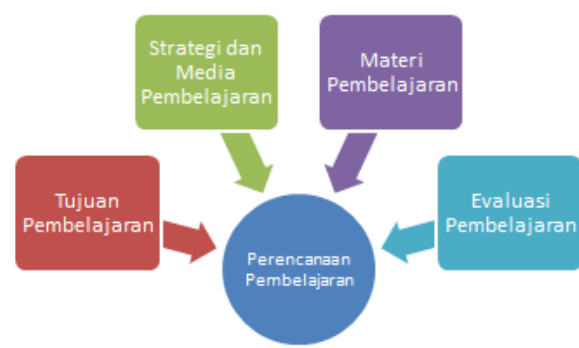

Gambar 4. Komponen Perencanan Pembelajaran

Kegiatan perencanaan pembelajaran mencakup setidaknya empat aspek seperti terlihat pada Gambar 4. Empat aspek yang dimaksud yaitu penentuan tujuan pembelajaran, strategi dan media pembelajaran, materi yang akan diberikan, serta bentuk evaluasi yang akan digunakan. Dengan memperhatikan empat aspek tersebut, maka seorang guru dapat dikatakan telah mampu membuat perencanaan yang matang dalam proses pembelajaran.

Tujuan pembelajaran yang baik seyogyanya berisikan muatan pengetahuan (kognitif), sikap (afektif) dan keterampilan (psikomotorik) untuk siswa setelah mempelajari suatu materi (Hendratmoko et.al., 2017). Melalui disusunnya tujuan pembelajaran, maka diharapkan pengajar dan siswa yang akan diajar memperoleh sebuah titik temu dalam aktivitas pembelajaran, Karena tujuan akan sangat berpengaruh pada strategi yang akan diterapkan. Adapun dalam pemberian materi Pendidikan Agama Hindu kepada siswa Pasraman Amertha Sanjiwani bertujuan untuk memberikan pengetahuan sekaligus penanaman nilai-nilai karakter kepada para siswa.

Setelah menentukan tujuan dari pembelajaran yang hendak dilakukan, selanjutnya ditentukan materi yang akan diberikan. Materi Pendidikan Agama Hindu yang akan diberikan tentunya dibedakan dengan materi pada umumnya yang diberikan di sekolah formal. Hal ini dikarenakan para siswa pasraman juga merupakan siswa yang duduk di bangku sekolah formal, tepatnya siswa yang duduk di kelas 3-6 Sekolah Dasar. Materi yang dipilih adalah Ajaran Hindu Dharma Tentang Etika (Susila). Muatan yang dicakup dalam materi ini adalah ajaran Tat Tram Asi, 
ajaran Subhakarma (Tri Kaya Parisudha dan Catur Paramitha), dan ajaran Asubhakarma (Tri Mala dan Catur Pataka). Pemilihan materi tersebut, tidak terlepas dari garis besar ajaran Hindu yang bagi menjadi tiga, yaitu Tattva, Susila dan Acara atau yang lebih dikenal dengan Tiga Kerangka Agama Hindu (Sariani, 2020).

Pemilihan materi akan mampu mencapai hasil yang baik apabila menerapkan strategi dan media pembelajaran yang tepat. Berkaitan dengan strategi pembelajaran yang direalisasikan dalam bentuk metode pembelajaran, Sutriyanti (2020) menjelaskan ada dikenal Metode Sad Dharma yang mencakup Dharma Wacana, Dharma Tula, Dharma Santi, Dharma Gita, Dharma Yatra, dan Dharma Sadhana. Dan diantara enam metode dalam Sad Dharma, metode yang diterapkan dalam kegiatan pengabdian adalah metode Dharma Wacana dan Metode Dharma Tula.

Metode Dharma Wacana merupakan metode mengajar dengan tekhnik ceramah secara oral, sehingga guru lebih dominan dalam menyampaikan materi. Sedangkan Metode Dharma Tula adalah metode mengajar yang lebih menekankan pada adanya feedback atau umpan balik antara siswa dan guru sehingga terwujud dalam tanya jawab atau diskusi. Selain dua metode tersebut, juga diterapkan metode demonstrasi dalam pembelajaran. Metode demonstrasi dilakukan dengan menunjuk salah seorang siswa untuk mempraktekkan skenario yang telah disiapkan (demonstrasi) dan siswa yang lain memperhatikan sambil melakukan penilaian. Hal ini tentunya dilakukan setelah penyampaian materi sebelumnya oleh guru (Dewi, 2018). Penggunaan tiga metode ini dalam pembelajaran Pendidikan Agama Hindu pada kegiatan pengabdian dimaksudkan agar siswa bisa memperoleh pemahaman akan ajaran susila yang kemudian dikorelasikan dengan konteks kehidupan bermasyarakat disana yang diharapkan mampu mempermudah siswa dalam memahami. Selain itu digunakannya lebih dari satu metode dalam pembelajaran pendidikan Agama Hindu dikarenakan tujuan pembelajaran yang hendak dicapai merupakan tujuan yang lebih umum, yaitu menanamkan nilai-nilai Pendidikan Agama Hindu (Wiguna \& Dewi, 2020).

Selain strategi pembelajaran, keberadaan media pembelajaran juga sangat penting guna menunjang aktivitas pembelajaran. Menurut Wahyuningtyas \& Sulasmono (2020) media pembelajaran dapat dijadikan sarana oleh guru dalam upaya menyampaikan muatan materi dengan cara yang kreatif sehingga membangkitkan motivasi belajar siswa. Sebagai penjelasan Wahyuningtyas, maka dapat dipahami bahwa keberadaan media pembelajaran menjadi hal yang perlu diperhatikan. Media pembelajaran kerapkali dikenal dengan istilah Alat Bantu Pembelajaran (ABP) karena memang dengan adanya media pembelajaran, guru lebih dipermudah dalam mengajar. Manfaat dari adanya media pembelajaran, (1) guru dapat mengonkretkan sesuatu yang abstrak, (2) dapat menampakkan sesuatu yang jauh, (3) menghadirkan sesuatu yang sudah terjadi, dan manfaat lainnya.

Media pembelajaran yang dipersiapkan untuk pembelajaran Pendidikan Agama Hindu di Pasraman Amertha Sanjiwani adalah menjadikan guru sebagai Human Medium, yaitu guru sebagai media utama dalam pembelajaran. Dalam konsep ini, guru akan menyampaikan konsep-konsep ajaran Susila, kemudian dengan pendekatan humanis berupaya mentransfer pemahaman siswa dalam bentuk praktek (metode demostrasi) untuk ditonton dan diambil nilainya oleh para siswa. Tujuan pembelajaran yang sudah ditentukan, ditunjang dengan pemilihan materi yang sesuai dan pemanfaatan strategi serta media yang tepat tentunya akan memberikan titik aman bagi seorang guru dalam mengajar. Demikian pula dengan pembelajaran Pendidikan Agama Hindu pada Pengabdian kepada Masyarakat di Pasraman Amertha Sanjiwani, dengan perencanaan yang sudah ada maka proses pembelajaran akan dapat berlangsung dengan baik. Namun sebelum itu, perlu diperhatikan instrumen evaluasi yang akan digunakan untuk mengukur keberhasilan pembelajaran Pendidikan Agama Hindu yang dilakukan.

Evaluasi Pembelajaran yang dipilih berupa evaluasi secara kualitatif, maksudnya bahwa tidak ada tes ataupun tugas yang diberikan kepada siswa, melainkan akan dilihat dari perubahan perilaku sehari-hari yang ditunjukkan oleh para siswa. Keberhasilan proses pembelajaran akan terjadi apabila siswa mampu menunjukkan perubahan perilaku sosialnya menjadi lebih beradab, baik dalam interaksinya dengan guru pasraman, tim pengabdian, maupun dengan teman sejawat.

\section{Penanaman Nilai Pendidikan Agama Hindu}

Penanaman nilai kepada siswa pertama dan utama diperoleh melalui lingkungan keluarga, dan nantinya pendidikan nilai yang diperoleh oleh siswa melalui keluarga akan berkontribusi pada pembentukan karakter siswa (Sri, 2012). Hal ini mengindikasikan bahwa setiap siswa yang menempuh pendidikan baik pada jalur formal maupun 
nonformal selalu membawa nilai-nilai yang diperoleh di keluarga. Bagi siswa yang sudah memiliki karakter yang baik akan mempermudah peran guru dalam pendidikan formal ataupun nonformal. Akan tetapi apabila siswa memiliki karakter yang kurang baik, maka tugas berat sudah menanti sosok guru.

$$
\text { Karakter seseorang biasanya }
$$

berbanding lurus dengan sikap kebertuhanan yang dimiliki oleh seseorang. Hal ini dimaknai bahwa seseorang yang bertuhan akan diikuti oleh tumbuhnya kepribadian positif yang melahirkan insan berkarakter. Orang yang berketuhanan atau berbhakti ditandai dengan perilaku yang menunjukkan aplikasi ajaran Daiwi Sampad, atau perilaku yang menunjukkan perilaku yang disenangi para dewa. Begitu pula dengan proses pembentukan karakter sesorang dimaksudkan sebagai upaya menjadikan manusia memiliki sifat-sifat dewa, atau diistilahkan dengan devatanisasi insani. Karakter merupakan cerminan penanaman nilai dan sikap yang didasarkan pada pengetahuan akan nilai dan sikap. Penanaman nilai dilakukan untuk membentuk anak manusia menjadi manusia seutuhnya (Rudiarta, 2020).

Mengorelasi sikap berketuhanan dan pembentukan karakter, menempatkan pembelajaran Pendidikan Agama Hindu sebagai salah satu upaya tepat yang dapat dilakukan. Dalam pengabdian kepada Masyarakat Prodi Pendidikan Agama Hindu STAHN Gde Pudja Mataram, penulis mendapat tugas dan tanggung jawab ini. Pembelajaran Pendidikan Agama Hindu pada Pengabdian sebagaimana disebutkan pada pembahasan sebelumnya menekankan pada konsep ajaran Susila. Konsep ajaran Susila yang ditanamkan kepada siswa nantinya diharapkan akan tercermin dalam perbuatan atau tingkah laku siswa. Hanya dengan mampu mengaplikasikan nilai-nilai baik (susila) tersebut siswa disebut sebagai orang yang berkarakter atau berakhlak (Ainiyah, 2013). Menurut Murtini dkk (2019), proses Internalisasi Nilai Pendidikan Agama Hindu Dalam Membentuk Siswa Berkarakter Mulia melalui beberapa tahap, yang meliputi Proses Pembelajaran, Pembiasaan, Keteladanan, Pengembangan Budaya Sekolah dan Kegiatan Ekstrakurikuler. Mengadopsi konsep yang dikemukakan Murtini dkk, dalam kegiatan di Pasraman, proses penanaman nilai pendidikan Agama Hindu dapat dilakukan dengan Proses Pembelajaran, Pembiasaan, Keteladanan, Mengembangkan Kultur Masyarakat, dan Pengintensifan kegiatan Pasraman. Akan tetapi pada kegiatan pengabdian kepada Masyarakat, Tim Pengabdian baru bisa melakukan proses Pembelajaran, Pembiasaan dan Keteladanan.
Sedangkan untuk mengembangkan Kultur Masyarakat dan Pengintensifan Kegaitan Pasraman lebih dititikberatkan pada Kepala Dusun dan Tetua Adat serta Pasraman Amertha Sanjiwani.

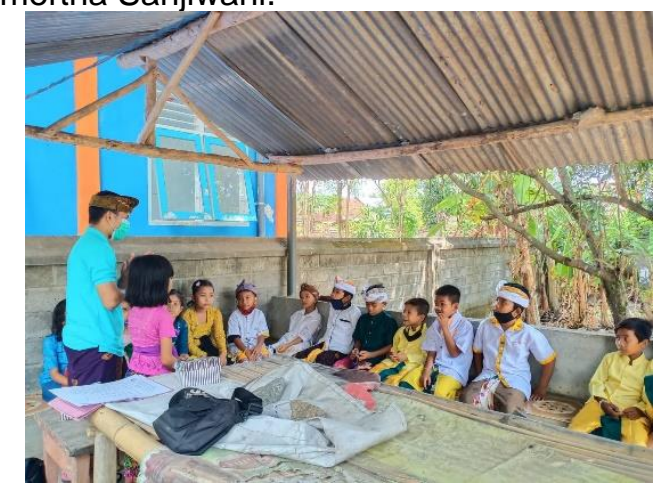

Gambar 5. Proses Pembelajaran Pendidikan Agama Hindu

(Sumber: I Wayan Rudiarta, 2020)

Proses Pembelajaran Pendidikan Agama Hindu pada saat Pengabdian kepada Masyarakat di Pasraman Amertha Sanjiwani diikuti oleh 24 siswa dan mengambil tempat pada ruang terbuka sebagaimana yang terlihat pada gambar 5. Dengan selalu memperhatikan protokol kesehatan Covid-19, pembelajaran di ruang terbuka akan membuat siswa merasa lebih nyaman. Selain proses pembelajaran ini mencoba berkiblat pada sistem pembelajaran upanisad yang dikenal pada pendidikan Hindu kuno. Upanisad merupakan sistem pembelajaran yang dilakukan dengan pendekatan partisipatif. Hal ini dimaksudkan bahwa siswa berupaya menggali sendiri suatu pengetahuan dengan jalan mengembangkan kemampuan dalam bertanya, kemampuan dalam berdiskusi, kemampuan dalam meneliti perilaku di alam sekitarnya serta pengembangan berbagai kemampuan yang lain (Suadnyana \& Yogiswari, 2019).

Melalui pembelajaran di ruang terbuka, di awali dengan pemberian materi dengan metode Dharma Wacana, kemudian dilanjutkan dengan adanya tanya jawab (Dharma Tula) berkaitan dengan materi yang sudah disampaikan. Diskusi dikaitkan dengan kehidupan sehari-hari masyarakat dan juga siswa sembari menyelipkan nilai-nilai karakter. Setelah acara diskusi selesai, dilanjutkan dengan metode demonstrasi, yaitu siswa diminta mempraktekkan suatu tindakan yang berkaitan dengan perilaku sehari-hari. Contohnya, ketika ketemu guru atau temannya, siswa memberikan salam "Om Swastyastu" yang berarti Semoga kita semua dalam keadaan sehat. Dengan metode ini, para siswa menjadi lebih terlatih untuk berbicara, selain untuk diajarkan untuk terbiasa melakukan tindakan yang berakhlak mulia. 
Murtini dkk (2019) dalam hasil penelitiannya di SD Negeri 2 Taman Bali menemukan bahwa Pendidikan Agama Hindu berimplikasi pada pembentukan beberapa karakter siswa seperti Karakter Siswa yang Religius (Sraddha dan Bhakti), Terbentuknya Karakter Siswa yang Disiplin (Yoga Sadhana), Terbentuknya Karakter Siswa yang Ramah Tamah dan Sopan Santun, Terbentuknya Karakter Siswa yang Jujur, dan Terbentuknya Karakter Siswa yang Peduli. Demikian halnya dengan pembelajaran Pendidikan Agama Hindu di Pasraman Amertha Sanjiwani diupayakan dapat membentuk Karakter Mulia pada siswa, paling tidak seperti hasil temuan Murtini dkk.

\section{Evaluasi Kegiatan Pembelajaran}

Sebagai tahap akhir dari kegiatan, maka diperlukan sebuah indikator yang menunjukkan kegiatan tersebut berhasil atau tidak. Demikian halnya dengan penanaman nilai Pendidikan Agama Hindu melalui kegiatan Pengabdian kepada Masyarakat di Pasraman Amertha Sanjiwani. Seperti yang telah diungkapkan sebelumnya, evaluasi keberhasilan dilakukan secara kualitatif, yaitu melihat perubahan karakter yang ditunjukkan oleh siswa selama kegaitan pengabdian yang berlangsung selama tujuh hari.

Secara kualitatif, dalam kurun waktu tujuh hari, terlihat ada beberapa perubahan yang terjadi pada diri siswa, yang dapat dideskripsikan sebagai berikut.

1. Sebagian besar siswa telah melakukan persembahyangan di rumahnya masing-masing sebelum mengikuti kegiatan pengabdian yang menunjukkan karakter religius (Sraddha dan Bhakti).

2. Siswa datang ke Pasraman sebelum tim tiba, padahal pada hari pertama, tim pengabdian yang menunggu kehadiran para siswa. Hal ini menunjukkan karakter Disiplin mulai terbentuk pada siswa.

3. Ketika tim pengabdian tiba, disambut dengan senyuman serta salam "Om Swastyastu" dari siswa, padahal pada saat melakukan Survei lokasi, siswa bersikap acuh dan mengucap say hello dengan meneriakkan "woy". Hal ini menunjukkan karakter ramah tamah dan sopan santun mulai tertanam.

4. Ketika berlangsung kegiatan pengabdian, tidak jarang terlihat para siswa mau meminjamkan pensil, penghapus ataupun pen kepada temannya yang tidak membawa, hal ini menunjukkan karakter Peduli sudah mulai tumbuh.

Dengan adanya beberapa perubahan perilaku yang ditunjukkan oleh para siswa selama kegiatan Pengabdian kepada Masyarakat, maka secara kualitatif dipandang bahwa penanaman nilai pendidikan Agama Hindu telah berlangsung dengan baik, walaupun belum maksimal. Dan selanjutnya, menjadi tugas masyarakat serta pihak pasraman untuk tetap menjaga benih-benih karakter mulia yang telah tertanam pada diri siswa.

\section{SIMPULAN DAN SARAN Simpulan}

Kegiatan Penanaman Nilai-nilai Pendidikan Agama Hindu melalui kegiatan Pengabdian kepada Masyarakat oleh Prodi Pendidikan Agama Hindu STAHN Gde Pudja Mataram dapat terlaksana dengan baik. Dalam waktu yang terbatas, siswa pasraman mampu diarahkan untuk mengembangkan nilai-nilai Pendidikan Agama Hindu seperti sikap Religius (Sraddha dan Bhakti), sikap Disiplin (Yoga Sadhana), Sikap Ramah dan Sopan Santun serta Sikap Peduli. Di tengah Pandemi Covid19 pembelajaran dilakukan dengan memperhatikan protokol kesehatan secara ketat. Pembelajaran juga dilakukan dengan berbasis pada kebutuhan siswa, dan hal ini berimplikasi positif pada meningkatnya motivasi siswa untuk mengikuti seluruh rangkaian kegiatan Pengabdian.

\section{Saran}

Diperlukan peran besar masyarakat untuk tetap menjaga tumbuh kembang para siswa Pasraman yang merupakan generasi muda Hindu sehingga tumbuh menjadi insan yang berkarakter dan mampu mengimplementasikan nilai-nilai Pendidikan Agama Hindu. Tokoh Masyarakat harus berperan besar dalam mengembangkan kultur positif dalam masyarakat, begitu juga dengan pihak Pengelola Pasraman. Pihak Pengelola, selain membantu berkembangnya kultur positif di masyarakat, juga diharapkan selalu menyelenggarakan kegiatan Pasraman secara rutin. Hal ini dimaksudkan untuk mengurangi kemungkinan lahirnya kebiasaan-kebiasaan negatif pada siswa yang akan mengancam masa depan generasi muda Hindu.

\section{UCAPAN TERIMA KASIH}

Ucapan terimakasih disampaikan kepada lembaga STAHN Gde Pudja Mataram, yang sekarang sudah beralih status menjadi IAHN Gde Pudja Mataram karena sudah 
memfasilitasi pelaksanaan pengabdian kepada Masyarakat Prodi Pendidikan Agama Hindu. Terima kasih pula disampaikan kepada pihak Masyarakat Dusun Rincung, Desa Banyu Urip, Kecamatan Gerung dan Pengelola Pasraman Amertha Sanjiwani yang telah menerima tim pengabdian dengan tangan terbuka dan penuh kehangatan sehingga seluruh rangkaian kegiatan pengabdian kepada Masyarakat dapat terlaksana dengan baik.

\section{DAFTAR RUJUKAN}

Ainiyah, N. (2013). Pembentukan Karakter Melalui Pendidikan Agama Islam. AlUlum: Jurnal Studi Islam, 13(1), 25-38.

Dewi, E. R. (2018). Metode Pembelajaran Modern Dan Konvensional Pada Sekolah Menengah Atas. PEMBELAJAR: Jurnal IImu Pendidikan, Keguruan, Dan Pembelajaran, 2(1), 44. https://doi.org/10.26858/pembelajar.v2i1. 5442

Gunada, I. W. A., Dyatmika, G. E. P., \& Weda, I. G. L. N. (2021). Pelatihan Dan Pembelajaran Aksara Bali Pada AnakAnak Di Pasraman Amerta Sanjiwani. Selaparang: Jurnal Pengabdian Masyarakat Berkemajuan, 4(2), 155-164. http://journal.ummat.ac.id/index.php/jpmb /article/view/4136

Hendratmoko et.al. (2017). Tujuan Pembelajaran Berlandaskan Konsep Pendidikan Jiwa Merdeka Ki Hajar Dewantara. Jinotep, 3(2), 152-157.

Murtini, P., Wardhani, N. K. S. K., Sugita, I. W., Sudarsana, I. K., \& Hendrawathy Putri, I. D. A. (2019). Internalisasi Nilai Pendidikan Agama Hindu Dalam Membentuk Siswa Berkarakter Mulia. Jurnal Penelitian Agama Hindu, 3(2), 175. https://doi.org/10.25078/jpah.v3i2.1138

Nadlir, M. (2013). Perencanaan pembelajaran berbasis karakter. Jurnal Pendidikan Agama Islam (Journal of Islamic Education Studies), 1(2), 338-352.

Ni Komang Sutriyanti. (2020). METODE PEMBELAJARAN PASRAMAN HINDU (Dalam Membentuk Karakter Anak Didik).
Rudiarta, I. W. (2020). CATUR PARAMITA SEBAGAI PENDEKATAN LATIHAN YOGA ASANA DI STAHN GDE PUDJA MATARAM. MEDIA BINA ILMIAH, 14(11), 3345-3356.

Rudiarta, I. W. (2020). Implikasi Latihan Yoga Asana Bagi Pembentukan Karakter Siswa Di Ashram Gandhi Puri Sevagram Klungkung. Jurnal Penelitian Agama Hindu, 4(1), 24-33.

Santika, N. W. R. (2018). Pendidikan Agama Hindu Sebagai Dasar Dalam Pembentukan Karakter. Satya Widya: Jurnal Studi Agama, 1(2), 153-163. https://doi.org/10.33363/swjsa.v1i2.47

Sariani, R. (2020). Peranan Pasraman Dalam Meningkatkan Sradha Dan Bhakti AnakAnak. WIDYALAYA: Jurnal IImu Pendidikan, 1(2), 201-208.

Sri, W. (2012). The nation's Character Building Through Value Education. Jurnal Pendidikan Karakter, 1(2), 55-66.

Suadnyana, I. bagus P. eka, \& Yogiswari, K. S. (2019). Upanisad Perspektif Pendidikan Modern. Jurnal PASUPATI, 6(2), 88. https://doi.org/10.37428/pspt.v6i2.136

Subagia, N. (2016). Keberadaan Pasraman Sebagai Penguatan Budaya Lokal Dikaitkan Dengan Peraturan Pemerintah Nomor 55 Tahun 2007. Jurnal Penelitian Agama , II(2), 31-68.

Wahyuningtyas, R., \& Sulasmono, B. S. (2020). Pentingnya Media dalam Pembelajaran Guna Meningkatkan Hasil Belajar di Sekolah Dasar. Edukatif: Jurnal IImu Pendidikan, 2(1), 23-27. https://doi.org/10.31004/edukatif.v2i1.77

Wiguna, I. B. A. A., \& Dewi, K. A. T. R. (2020). Strategi Guru Dalam Peningkatan Mutu Pembelajaran Etika Hindu. Jurnal Penjaminan Mutu, 6(2), 210-220.

Yasa, I. M. A. (2021). Optimalisasi Pengabdian Masyarakat Pada Sekolah Paud Binaan. Selaparang: Jurnal Pengabdian Masyarakat Berkemajuan, 4(2), 179-187. http://journal.ummat.ac.id/index.php/jpmb /article/view/4387 